\title{
Time course of bronchoconstrictive response in asthmatic subjects to reduced temperature
}

\section{J. M. RAMSEY}

From the Department of Biology, University of Dayton, Ohio, USA

Ramsey, J. M. (1977). Thorax, 32, 26-28. Time course of bronchoconstrictive response in asthmatic subjects to reduced temperature. Thirteen young adults with bronchial asthma and a like number of controls were subjected for 45 minutes to a temperature of $2^{\circ} \mathrm{C}$ after leaving a temperature of $24^{\circ} \mathrm{C}$ to which they subsequently returned. Pre-exposure examination included $\mathrm{VC}, \mathrm{FEV}_{1}, \mathrm{MMEF}, \mathrm{FEV}_{1} / \mathrm{VC} \%$, and urinary catecholamines. The pulmonary measurements were repeated at 15, 80, and 200 minutes after exposure. Catecholamines were measured from a second urine sample, the collection of which corresponded to the period during and after the stress.

Controls showed no significant pulmonary changes throughout the time of study, but 15 minutes after exposure the asthmatic subjects showed a significant mean decrease of all pulmonary measurements from pre-exposure values. The controls showed a significant mean increase in urinary catecholamines after the stress, whereas those with asthma showed no significant increase.

Strong statistical correlations have been demonstrated between cold weather fronts and asthmatic bronchoconstriction (Greenburg et al., 1966; Tromp, 1968). Furthermore, statistical data suggest that the distress may persist for a time after the meteorological change (Ramsey, 1976).

The experiments of Wells et al. (1960) and Simonsson et al. (1967) have shown that when patients with respiratory disease inhaled air at -20 to $-30^{\circ} \mathrm{C}$ for $2-3$ minutes, the majority experienced increases in airway resistance that immediately returned to control levels when cold air was no longer being inhaled. Simonsson et al. (1967) concluded that cold air sensitises cough receptors which stimulate a localised bronchoconstrictive reflex via cholinergic pathways.

Cabezas et al. (1971) have shown that when vagal bronchoconstriction is present in dogs, electrical stimulation of sympathetic nerves reverses the bronchoconstriction. Szentivanyi (1968) has postulated that the basic defect in bronchial asthma is an insufficient adrenergic responsiveness to stress. Mathé and Knapp (1969) reported a less than normal rise in urinary adrenaline levels in six asthmatic patients subjected to controlled psychic stress. Also Barboriak et al. (1972) showed that asthmatic subjects fail to exhibit the expected increase in plasma nonesterified fatty acids in response to exercise, presumably because of de-
creased release of adrenaline.

The following controlled experiments were designed to resolve whether or not those witho asthma show significant bronchoconstriction in response to a single chill stress, and in particularo to determine how long the bronchoconstriction. persists after the exposure. In addition, the studyô was to determine if asthmatic subjects show a₹ difference from controls in mobilisation of cate-음 cholamines as a consequence of the exposure.

\section{Methods}

Thirteen non-smoking university students (4 fe- 0 male) with a diagnosis of bronchial asthma werew carefully screened and selected for the study Those selected were 19-23 years of age, in goodo health apart from the asthma, and had not beenos on medication or had asthma attacks for three weeks before the study. Thirteen additional nonsmoking subjects of matched age ( 2 female) and in good health with no evidence of pulmonary disease were recruited as controls. The studieso were conducted during the winter when outdoor airborne allergens were not present. 
When reporting to the laboratory (one at a time) each subject brought a 24-hour volume of urine and proceeded to acclimatise at rest to a temperature of $24^{\circ} \mathrm{C}$ and relative humidity of $45 \%$. Total catecholamines were measured from the urine sample by the method of Jacobs $e t$ al. (1961) and read fluorometrically. Determinations in duplicate were done for vital capacity (VC), forced expiratory volume at 1 second $\left(\mathrm{FEV}_{1}\right)$, and maximal midexpiratory flow (MMEF) with a Warren E. Collins 13.5 litre respirometer. Percentages for $\mathrm{FEV}_{1} / \mathrm{VC}$ were calculated and all values were corrected to BTPS. Measurements of flow rates were chosen rather than airways resistance in view of the contention of McFadden and Lyons (1968) that airflow obstruction can reside in lower airways despite normality of total airway resistance. Bouhuys et al. (1970) also indicate that in many instances of bronchoconstriction there are decreases of $\mathrm{VC}$ and maximal flows with little change in resistance.

Each subject was exposed to a temperature of $2 \circ \mathrm{C}$ with a controlled relative humidity of $45 \%$ for 45 minutes in a large, well-ventilated, walk-in environmental chamber (Scherer, model CER810) and then returned to a temperature of $24^{\circ} \mathrm{C}$. During the time in the chamber the subject sat at rest. They were reasonably clothed with typical street wear such as a heavy sweater, but the head and hands were bare. Most of them felt cold and tended to shiver by the end of the 45 minutes. Spirometric measurements were repeated at intervals of 15,80 , and 200 minutes after the exposure. A second urine sample (24-hour volume, inclusive of the time of the stress) was collected for catecholamine estimation.

\section{Results}

PULMONARY EVALUATION

The time course of means for both groups is shown in Tables 1 and 2 . Controls showed no significant changes throughout the time course

Table 1 Time course of mean pulmonary values in 13 controls exposed to a temperature reduction of $22^{\circ} \mathrm{C}$ for 45 minutes

\begin{tabular}{lrrrr}
\hline \multicolumn{5}{c}{ Postexposure } \\
\cline { 3 - 5 } & Pre-exposure & & \\
\cline { 3 - 5 } & & 15 min & $80 \min$ & $200 \mathrm{~min}$ \\
\hline $\mathrm{VC}(1)$ & $4.84 \pm 0.861$ & $4.89 \pm 0.90$ & $4.88 \pm 0.99$ & $4.88 \pm 0.99$ \\
$\mathrm{FEV}_{1}(1)$ & $4.16 \pm 0.59$ & $4.16 \pm 0.57$ & $4.10 \pm 0.57$ & $4.19 \pm 0.69$ \\
$\mathrm{MMEF}(1 / \mathrm{sec})$ & $4.76 \pm 0.70$ & $4.74 \pm 0.80$ & $4.72 \pm 0.78$ & $4.71 \pm 0.70$ \\
$\mathrm{FEV}_{1} / \mathrm{VC}(\%)$ & $86.91 \pm 7.75$ & $86.66 \pm 5.43$ & $86.84 \pm 4.87$ & $86.50 \pm 5.85$
\end{tabular}

'Standard deviation.
Table 2 Time course of mean pulmonary values in 13 asthmatic subjects exposed to a temperature reduction of $22^{\circ} \mathrm{C}$ for 45 minutes

\begin{tabular}{|c|c|c|c|c|}
\hline & \multirow{2}{*}{ Pre-exposure } & \multicolumn{3}{|l|}{ Postexposure } \\
\hline & & $15 \min ^{2}$ & $80 \mathrm{~min}$ & $200 \min$ \\
\hline $\begin{array}{l}\text { VC (1) } \\
\text { FEV }_{1}(1) \\
\operatorname{MMEF}(1 / \mathrm{sec}) \\
\operatorname{FEV}_{1} / \operatorname{VC}(\%)\end{array}$ & $\begin{array}{r}4.72 \pm 1.01^{1} \\
3.78 \pm 0.83 \\
3.87 \pm 1.34 \\
80.77 \pm 7.65\end{array}$ & $\begin{array}{r}4 \cdot 56 \pm 0.92 \\
3 \cdot 58 \pm 0 \cdot 77 \\
3 \cdot 50 \pm 1 \cdot 24 \\
77 \cdot 30 \pm 7 \cdot 45\end{array}$ & $\begin{array}{r}4.67 \pm 0.90 \\
3.65 \pm 0.73 \\
3.65 \pm 1.03 \\
79.18 \pm 5.30\end{array}$ & $\begin{array}{r}4.71 \pm 0.99 \\
3.72 \pm 0.76 \\
3.79 \pm 1.18 \\
79.88 \pm 6.31\end{array}$ \\
\hline
\end{tabular}

'Standard deviation.

${ }^{2}$ All means significantly different from pre-exposure.

(Table 1). However, 15 minutes after asthmatic subjects had returned to $24^{\circ} \mathrm{C}$ they showed mean reductions from pre-exposure values that are significant by paired $t$ test for VC $(P<0.01)$, $\mathrm{FEV}_{1}(\mathrm{P}<0.01)$, MMEF $(\mathrm{P}<0.001)$, and $\mathrm{FEV}_{1} /$ VC $\%(P=0.05)$ (Table 2$)$. Twelve of 13 subjects showed a reduction in MMEF, and 11 of 13 experienced a reduction in $\mathrm{VC}, \mathrm{FEV}_{1}$, and $\mathrm{FEV}_{1} / \mathrm{VC}$. Though the means remained lower at 80 minutes than those before exposure (Table 2), the differences were not statistically significant. At 200 minutes the means for pulmonary function approximated those before exposure (Table 2 ).

\section{CATECHOLAMINE EVALUATIONS}

The mean for total catecholamines in controls before cold exposure was $50.9 \mu \mathrm{g} / 24$-hour volume $(\mathrm{SD} \pm 23.54)$. Catecholamines from their second urine sample had a mean of $69 \cdot 8 \mu \mathrm{g} / 24$-hour volume ( $\mathrm{SD} \pm 34.66)$, an increase that is significant by paired $t$ test $(\mathrm{P}<0.05)$. The pre-exposure mean for asthmatic subjects was $47 \cdot 5 \mu \mathrm{g} / 24$-hour volume $(\mathrm{SD} \pm 29.04)$, and that of their second sample only $50 \cdot 3 \mu \mathrm{g} / 24$-hour volume (SD \pm 24.25$)$, which is not a significant increase.

\section{Discussion}

Though the sample in this study is not large, it appears that i reduction in ambient temperature is capable of significantly reducing pulmonary flow rates in asthmatic subjects but not in normal individuals. Furthermore, the bronchoconstriction persists for more than 15 minutes after the subject once more inhales warm air. Although residual volume was not measured, the significant reduction in postexposure VC suggests elevation of RV. Permutt (1973) has pointed out that reduction of VC is characteristic of asthmatic distress.

If the bronchoconstrictive effect is mediated by the stimulation of cough receptors, as 
postulated by Simonsson et al. (1967), then those with asthma either have a lower receptor threshold for initiating the response or less ability to counteract vagal firing. The persistence of the bronchoconstriction for some time after removal of the stimulus could mean either that the receptors remain sensitive or that counteraction, possibly related to adrenergic response, is not as effective in asthmatic subjects. The lesser catecholamine excretion among asthmatic subjects in response to the cold stress in this study is in favour of the latter. Jansky et al. (1967) have demonstrated that normally there is a significant release of catecholamines which enhance thermogenesis in animals exposed to cold. Of course other stresses, such as the reaction to coming to the laboratory, may have been a factor affecting catecholamine levels.

This study was supported by the Miami Valley Lung Association (Ohio-USA) and the University of Dayton Research Council. Bonnie Korchmaros, Jean Callander, Gregg Rouan, Ann Lenane, and Lawrence Staubach provided technical assistance.

\section{References}

Barboriak, J. J., Sosman, A. J., Maksud, M. G., and Fink, J. N. (1972). Metabolic changes in patients with postexercise asthma (Abstract). Journal of Allergy and Clinical Immunology, 49, 116.

Bouhuys, A., van de Woestijne, K. P., Kane, G., and van Wayenburg, J. (1970). Respiratory mechanics and dust exposure in byssinosis. Journal of Clinical Investigation, 49, 106-118.

Cabezas, G. A., Graf, P.D ., and Nadel, J. A. (1971). Sympathetic versus parasympathetic nervous regulation of airways in dogs. Journal of Applied Physiology, 31, 651-655.

Greenburg, L., Field, F., Reed, J. I., and Erhardt, C. L. (1966). Asthma and temperature change. Archives of Environmental Health, 12, 561-563.
Jacobs, S. L., Sobel, C., and Henry, R. J. (1961). Specificity of the trihydroxyindole method for deter-음 mination of urinary catecholamines. Journal of Clinical Endocrinology and Metabolism, 21, 305- $\widehat{\varnothing}$ 314.

Jansky, L., Bartunkova, R., and Zeisberger, Eڤ 1967). Acclimation of the white rat to cold; $\vec{\circ}$ noradrenaline thermogenesis. Physiologia Bohemo slovenica, 16, 366-372.

McFadden, E. R., Jr. and Lyons, H. A. (1968). Airway resistance and uneven ventilation in brenchiaP asthma. Journal of Applied Physiology, 25, 365-370 $\omega_{\text {W }}$

Mathé, A. A. and Knapp, P. H. (1969). Decreased plasma free fatty acids and urinary epinephrine ini bronchial asthma. New England Journal of Medicine, 281, 234-238.

Permutt, S. (1973). Physiologic changes in the asthmatic attack. In Asthma: Physiology, Immuno pharmacology, and Treatment, edited by $\mathrm{K}$. FO Austen and L. M. Lichtenstein, p. 16. Academicg Press, New York and London.

Ramsey, J. M. (1976). The relation of urban atmos $\overrightarrow{0}$ pheric variables to asthmatic bronchoconstriction. Bulletin of Environmental Contamination and Toxicology, 16, 107-111.

Simonsson, B. G., Jacobs, F. M., and Nadel, J. A (1967). Role of autonomic nervous system and the cough reflex in the increased responsiveness of air ways in patients with obstructive airway disease Journal of Clinical Investigation, 46, 1812-1818.

Szentivanyi, A. (1968). The beta adrenergic theory o the atopic abnormality in bronchial asthma. Journat of Allergy, 42, 203-232.

Tromp, S. W. (1968). Influence of weather and climate. on asthma and bronchitis. Review of Allergy, 22 1027-1044.

Wells, R. E., Jr., Walker, J. E. C., and Hickler, R. BQ (1960). Effects of cold air on respiratory airflow resistance in patients with respiratory-tract disease 3 . New England Journal of Medicine, 263, 268-273.

Requests for reprints to: Dr. J. M. Ramsey, Depart? ment of Biology, University of Dayton, Dayton, Ohiop USA. 